\title{
Red tape strangles basic research grants
}

\section{European Research Council finds itself mired in bureaucracy.}

\section{EXCLUSIVE}

The European Commission's strict rules on finance and administration are hampering efforts by the European Research Council (ERC) to fund scientists, Nature has learned. The rigid bureaucracy is causing peer reviewers to desert the grant-review process, and some worry it could threaten the future viability of the council.

The ERC was set up two years ago as a panEuropean initiative to fund frontier research judged solely on excellence. At the time, many scientists urged that it should be kept free of the European Commission's notoriously complex bureaucracy (see Nature 436, 441-442; 2005). They had hoped that the council would be responsible for its own budget and be allowed to create its own rules on administration, structure and employment. But ultimately it was created as an executive agency run through the commission.

Sources of frustration now emerging include the extensive requirements for documenting the time spent on work funded by the council, plus administrative delays in areas such as expense claims for peer reviewers.

"In general the scientific community is impressed by what the commission has done in establishing the ERC," says Ernst-Ludwig Winnacker, whose term as the council's secretary-general ended on 1 July. "But in time I think they will run out of patience."

On 23 July, a high-level panel "You want people to do first-rate frontier research and then you impose contractual obligations on them."

and accountable institution. And we are doing just that."

"We are of course committed to having the most efficient and appropriate structure for the ERC," adds José Manuel Silva Rodríguez, who heads the commission's research directorate responsible for the ERC.

The vision for the ERC was to give the best European researchers the freedom to explore ideas, through grants similar to those of the US National Science Foundation. So far, the council has selected around 600 projects for funding worth around $€ 900$ million (US $\$ 1.3$ billion).

The ERC's scientific strategy, priorities and peer-review process are established by its scientific council. Many would like to award researchers a lump sum with as few obligations as possible other than showing the fruits of their endeavours - publications, for instance - at the end of the project, as is done at many other funding agencies. But the ERC must follow the commission's legal rules in awarding contracts. Recipients of awards must negotiate in lineby-line detail how much money they need and on what it will be spent. And they must reach clear milestones with expected outcomes before receiving the next parcel of money.

"You want these people to do first-rate frontier research and then you impose contractual obligations on them. The symbolic value of this is obvious," says a member of the ERC's scientific council, who asked not to be named for fear that the commission might led by the former president of Latvia, Vaira Vike-Freiberga, will publish a review of the ERC's structure and governance. It is expected to comment on these problems and make recommendations to address them.

The commission is due to respond officially to the review in October. But speaking exclusively to Nature, Janez Potočnik, the European commissioner for research, agrees that some of the current rules are "too rigid" for organizations such as the ERC. "This needs to be looked at clearly, and we are doing it," he says.

If the ERC is to have a strong international reputation, he says, "the commission needs to work more on how to create an autonomous

\section{baulk at making changes.}

Unpaid peer reviewers of grant applications are also hit by red tape. They have to provide proof of their identity, which the commission must authorize, before they can be given any information about the applicant or the proposal they are being asked to review, says JeanPierre Bourguignon, chairman of the ERC's peer-review panel for young mathematicians.

"I have never seen anything like this for peer review," says Bourguignon, who heads the Institute of Advanced Scientific Studies (IHES) near Paris. A number of potential peer reviewers "refused to be involved", he adds. "They were very upset."

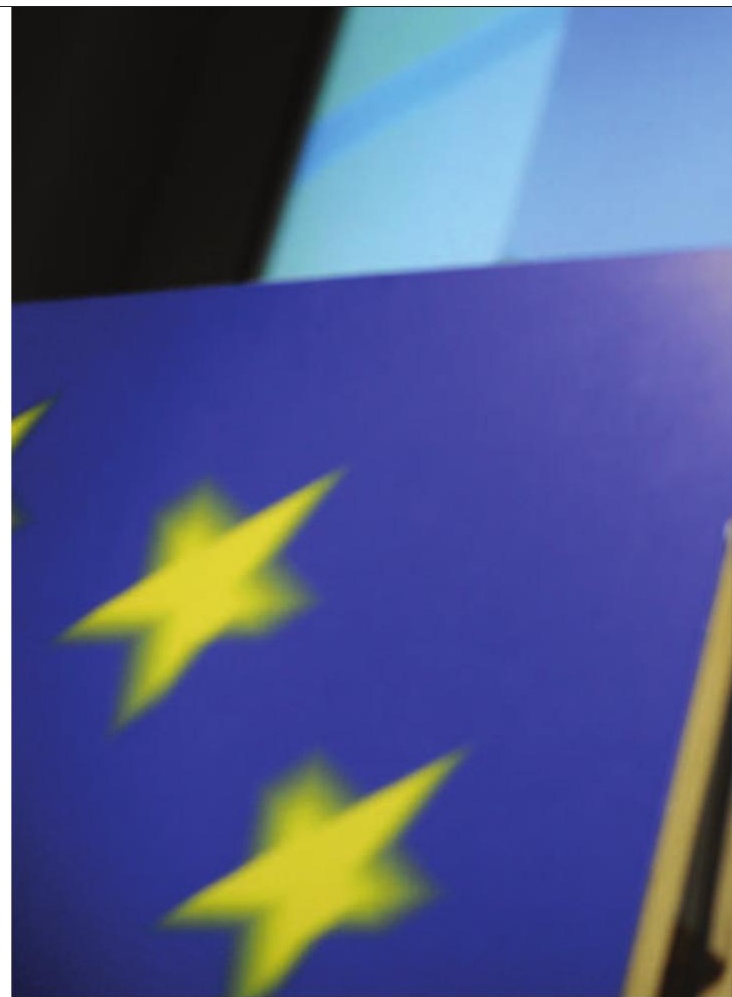

Janez Potočnik acknowledges the need for change at the European Research Council.

Bourguignon says he has had to write hundreds of e-mails to reviewers apologizing for the rules in an attempt to persuade them to help. He says that out of some 225 reviewers contacted over three grant rounds, two-thirds initially refused to help, and from that group he managed to salvage one-third.

The same problem has been experienced across all the panels, says the science council member. Other researchers who initially signed up to review dropped out in later rounds because the commission took three months to reimburse their travel costs.

Silva Rodríguez says that new procedures are being adopted to streamline processes such as the approval of outside peer reviewers. Travel expenses for overseas experts are now paid in about 20 days, he says.

\section{Teething troubles}

"We have wasted an enormous amount of energy trying to solve even the most minor of things that should not be causing any problem. Hopefully this difficult period is now over," says Helga Nowotny, vice-president of the ERC and a professor emeritus in social science at the Swiss Federal Institute of Technology in Zurich. She says the ultimate goal of the scientific council is for the ERC to be administratively and financially independent of the commission. 


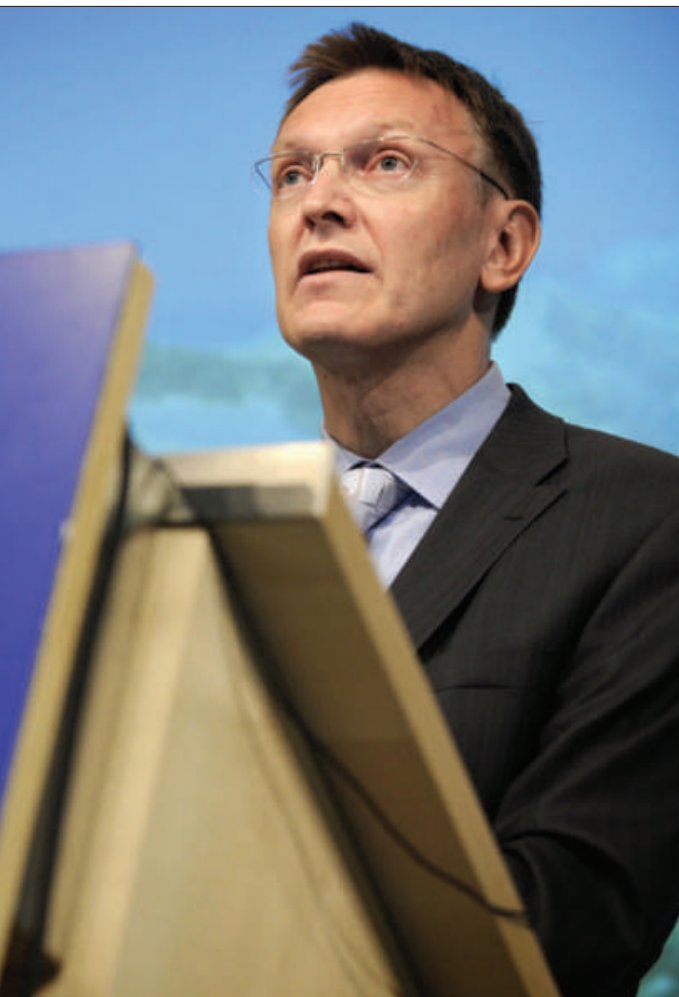

Winnacker, meanwhile, argues that power needs to shift away from the commission towards scientists. He suggests that the director of the executive agency, who authorizes each funding award, should be a scientist appointed by the scientific council, and that its steering committee should have a majority of scientists. Having scientists in charge, he says, could make it easier to solve some of the problems that the ERC has encountered because there is "room for interpretation" in the commission's rules.

Dieter Imboden, president of EUROHORCs, a group of the heads of Europe's research councils, agrees. "We wrote a letter to the commission in March about the problems the ERC was having," he says. "Mr Silva Rodríguez met with me to discuss the problems but said that there was nothing he could do. We don't accept this. He does not use the room for manoeuvre he has as the director-general for interpreting the rules."

"All my contacts so far with the scientific community, the European Union member states and research institutions have strongly reassured me that we, the commission and the scientific council, each with their respective responsibility, are on the right track," says Silva Rodríguez.

Potočnik's term ends in October, but he has time to follow up on the results of the ERC review before he leaves.

Natasha Gilbert

See Editorial, page 435.

\section{Cuts bite in California}

The ten-campus University of California (UC) system - a national star of US public universities - has begun haemorrhaging top researchers as its financial crisis escalates.

On 16 July, the UC board of regents voted to give its president Mark Yudof the power to force university staff to take unpaid leave through a furlough plan. The cuts are meant to help the system offset about a quarter of its US\$813-million drop in state funding this year. The measures would affect 108,000 full-time UC employees and would follow a sliding scale according to salary, with the lowest-paid faculty members drawing 11 unpaid days off - equivalent to a $4 \%$ pay cut - and the highest-paid staff drawing 26 unpaid days, or a $10 \%$ cut.

"The alternative is massive lay-offs," Yudof told the regents in San Francisco. "We have frankly just run out of money."

Those exempt from salary cuts include student employees, such as graduate students, as well as staff whose salaries are paid wholly from research grants and contracts. Most campuses have dramatically curtailed recruiting, including withdrawing job offers already made to candidates.

Marye Ann Fox, chancellor of the University of California, San Diego (UCSD), said at the regents' meeting that several top researchers had already left the system. In written comments naming some of them, she mentioned Edward Yu, a professor of electrical and computer engineering who is moving to the University of Texas at Austin, and biologist Charles Zuker, said to be moving to Columbia University in New York.

The separate, 23-campus California State University (CSU) system is also struggling - its budget from the state for the new fiscal year is $\$ 584$ million less than it was expecting. CSU executives are asking employee unions to agree to a twoday-a-month furlough, which represents a $9.5 \%$ pay cut, for 46,000 employees. The California Faculty Association, a key group that represents 23,000 faculty members from the CSU system, is voting on the proposed cut this week, with results likely to be tabulated on 22 July (after Nature went to press). If the faculty do not approve, CSU officials say that lay-offs are likely.

At the UC regents' meeting, meanwhile, some scientists argued that young faculty

members will be hit particularly hard by the cuts, and that it is already becoming difficult to recruit and retain them.

Astronomer Mark Krumholz of the University of California, Santa Cruz, says that if the cuts continue for longer than a year, he would consider leaving. "In one year, I have brought in nine times my salary in grants," he says. "If I go elsewhere, that money follows me."

Krumholz spearheaded the writing of a letter sent this month to California governor Arnold Schwarzenegger and members of the state legislature to protest against the cuts. It has been signed by more than 300 UC faculty members who are members of the US National Academies of Science or Engineering or of the Institute of Medicine.

Another signatory at the Santa Cruz campus, astronomer Sandra Faber, warned the regents that continued cuts would lead to serious harm. "The university is the most powerful economic engine in the state," she said. "Disinvesting in the University of California at this time is like eating our seed corn."

But the state continues to face a \$26-billion budget deficit; it must balance its books for each fiscal year, which began on 1 July. "I don't really see a light at the end of the tunnel," Yudof said last week. With Russell

RECESSION WATCH
Gould, chairman of the UC board of regents, he has announced plans to form a Commission on the Future of UC to examine the university's continued existence, its services and its funding model.

The cuts have even triggered fighting within the UC system itself, with some at the biggest campuses suggesting turning on the smaller ones. In a 15 June letter that made headlines last week, the chairman of UCSD's sociology department, Andrew Scull, and 22 other department chairs called on the regents to make the UC campuses at San Diego, Berkeley, Los Angeles and San Francisco into elite research institutions; other campuses would be downgraded to teaching institutions, with presumably smaller budgets.

As Nature went to press, the state legislature and the governor had agreed a plan to close the budget gap, involving some $\$ 15$ billion in proposed cuts.

Erika Check Hayden and Rex Dalton

For a video of UC protests over the cuts, see http://tinyurl.com/ucprotest 